\title{
5. SEASONAL LABOUR MIGRATION AND LIVELIHOOD IN THE MIDDLE HILL OF NEPAL: REFLECTIONS FROM ARGHAKHANCHI DISTRICT
}

- Kanhaiya Sapkota ${ }^{5}$

\begin{abstract}
People's livelihood in the villages of the middle hill of Nepal are based on farming system. The relationship between climate change and seasonal labor migration in the middle hill areas is a relatively understudied research topic, particularly from an empirical point of view. This article aims at contributing to the literature by analyzing the relationship between livelihoods and human mobility in two rural communities located in the Province 5, Arghakhanchi district, Nepal. Traditional rain-fed agriculture is the most important economic activity in the area. This article highlights differences in livelihood and human mobility patterns between households. The economy of the middle hill is primarily agrarian. Over $80 \%$ of the population of the middle hill districts still lives in rural areas/settings, where levels of poverty are higher than in the neighbouring countries. They depend on farming and collecting forest products for their livelihoods. In Arghakhanchi district, during the dry season, many migrate in search of temporary work as labourers particularly in Indian states. Arghakhanchi is the district where the proportion of inhabitants from low income is relatively higher than the other surrounding districts of Province 5. These people are marginalized and experience high rates of poverty, low levels of education and poor health. They are highly vulnerable to climate change, due to poverty and dependence on climate-sensitive livelihoods in a vulnerable region. Consequently, more households are likely to participate in seasonal migration and those already migrating are credible to do so for longer times. Currently, such migrants take up low-paying unskilled works, mainly in urban areas in Uttarakhand, Panjab and Bhopal of India, which enables them to make meager savings, hardly enough to repay the debt of their family has incurred during food shortages. In the study area, the non-agricultural diversification is widespread and income from non-agricultural activities exceeds agricultural income. However, though mobility patterns in the area are determined primarily by broader economic considerations.
\end{abstract}

Keywords: Seasonal migration, livelihood diversification, livelihood resilience.

\section{Introduction}

Seasonal labor migration to India was a dominant feature of rural poor communities of Nepal, consistent with open borders, and cultural similarities. Therefore, it has long been part of the livelihood portfolio of poor people across the country as well as a part of life of the poor people from the middle hill of Nepal. However, surprisingly with a few perceptible interest (Gautam, 2017), seasonal labor migration in the middle hill of Nepal is a little studied subject until the last few years. Nonetheless, it is now admitted that migration is a part of the livelihood strategy of the poor. Since the very beginning, seasonal migration of the rural poor was a common phenomenon 5 Mr. Sapkota is Associate Professor of Geography at TU 
in Nepal. The main cause of seasonal migration was labor migration to the Indian cities, i.e. Bhopal, Punjab and Uttarakhand for additional income. It is a common process and a part of their life. Traditionally, poor conditions for agricultural production, shortage of arable land and the lack of other off-farm opportunities drove them to see temporary employment (Olimova \& Olimov, 2007). Therefore, seasonal migration is widely acceptable adaptive strategy of the people from the rural communities/societies. Because of the lack of economic opportunities in the country, the rural families and the households appear to be increasing their dependence on seasonal labor migration to abroad and the remittances are likely to become critical resources for the sustenance of homes and families in the middle hill of Nepal.

Seasonal labor migration has been a large part of livelihood of most households in the middle hill of the country throughout its history. Thus, the rural farming households seek additional or alternative options for their betterment of their livelihoods other than farming in order to cope with poverty and to improve their living standards (see Acosta, Calderon, Fajnzylber \& Lopez, 2008). Remittances are an important source of income for both country and household levels (World Bank, 2017). According to a report of Labor Migration for Employment - A Status Report for Nepal: 2014/2015, there has been a huge increase in the amount of remittances, from 58.6 billion rupees (NPR) in 2003/04 to NPR589.5 billion in 2014/15. It contributed a 10.9 percentage share of the GDP in 2003/04 and 27.7 per cent in 2014/15, and it increased by 2.3 percent in 2016 and reached 30 percent of the total GDP ((World Bank, 2017). It is the second highest such percentage in the world (C.f. Gautam, 2017). It seems that the flow of remittance is a major source of economic development of the country.

Due to open border and cultural similarities with India, most of the poor rural migrants have better opportunities to work in major Indian cities. As a short-term seasonal migrant, people from the western middle hill prefer to go to the India cities without any work permit. Some of the remittances in the rural areas of the country are from seasonal work, and an important feature of Nepali labor migration to India is that much of it seasonal. However, it is clearly indicated that remittances from short-distance seasonal migration are much lower than those from longer-term international migration (Hollema, Pahari, Regmi, \& Adhikari, 2008). Labour migration can be an operative approach for livelihood adaptation in the rural communities in most of the rural part of the middle hill of Nepal. It helps to generate varieties of assets/capitals, i.e financial and human capital that can contribute to poverty reduction or alleviation of the rural areas, but it can have less welcome effects on communities. For the poor of the middle hills, remittances are increasingly the most direct, immediate, and noteworthy contribution to their livelihoods. However, those communities face particular challenges in benefiting from migration that are linked to the specific situation of their rural or hardship life.

Development and change effort generally pay little attention to the encounters and opportunities that must be faced to yoke the potential of labor migration and reduce the negative effects for those societies. One of the main reasons for this is the lack of information and knowledge on labor migration and remittance patterns and its volumes. Therefore, labor migration in the rural 
communities is a highly provoked process, with mostly male leaving and female staying behind. It is of particular importance to better understand the effects of this mostly male outmigration in order to develop gender sensitive solutions to improve the development relevance of remittances. However, the studies show that the short-term seasonal migrants generally sent low amount of money as remittances to their household than the long-term international migration (Hollema, Pahari, Regmi, \& Adhikari, 2008). Therefore, the seasonal labor migration is a fundamental aspect of rural livelihoods and a noticeable source of economic benefit in the poor communities of the middle hill of Nepal.

Due to the lack of proper studies on the impact of seasonal labor migration and its impact on the rural livelihoods, this study will support mainly on the seasonal labor migration from Arghakhanchi district as a case study and its impact on the socioeconomic and livelihoods of the poor communities in the middle hill of Nepal.

\section{Theoretical Perspectives}

Migration of people for labor is gaining importance globally, as the remittances migrants send home to their families account for a significant share of the overall household income, particularly so for poor households. Seasonal migration is one of the most common coping strategies adopted by poor households to stabilize their livelihoods and to adapt to climate, political and economic changes. It is also one of the only means for poor rural farm households to overcome shortfalls of seasonal agricultural income and employment.

Migration from one area to another in search of improved livelihoods is a key feature of human history (Srivastava \& Sasikumar, 2003). These moves might be of short to long distance as well as of short to long duration (Kosinski \& Prothero, 1975; Massey, 1990). It is evident from the available literature that there is a widespread occurrence of temporary and seasonal migration for employment in developing countries (Brauw, 2007; Deshingkar \& Farrington, 2006; Hugo, 1982; Lam et al., 2007; Mberu, 2006; Yang, 1992). Seasonal migration is also one of the most significant livelihood strategies, adopted among the poorest section in the middle hill of Nepal, predominantly in the form of seasonal mobility of labour (Breman, 1978; Breman, 1996; Deshingkar \& Farrington, 2009; Deshingkar \& Start, 2003; Haberfeld et al., 1999; Mosse et al., 2005; Rao \& Rana, 1997; Rogaly, 1998; Rogaly et al., 2001).

The livelihood approach departs from earlier narrow economics approaches and Marxist approaches of political and institutional analysis to understand migration as one of the strategies adopted by individuals, households or communities to enhance their livelihoods (Skeldon, 2002; Kothari, 2002; Ellis, 2000; 2003; de Haan, 1999; 2000; Deshingkar, 2004; McDowell \& de Haan 1997). Recent theories go beyond the Marxist and neo-classical economics interpretations by incorporating livelihoods and social exclusion perspectives (Deshingkar \& Start, 2003). According to Kothari (2002), livelihood strategies are diverse and multiple but migration remains a central component for many poor people in developing countries. 
Temporary migration, often used interchangeably with circular, seasonal, short-term and spontaneous migration, has been a subject of much discourse. It is a sort of mobility where the economic activity of a person is moved but not the usual residence (Bilsborrow et al., 1984). Researchers and statisticians differ on the definition of temporary migration in respect to the duration of stay. However, there is an agreement on the fact that the temporary but uninterrupted absence from the place of origin is an important condition for temporary migration (Hugo, 1982; Zelinsky, 1971). In essence, temporary migration is a move made for a short period of time with the intention of returning to the place of usual residence. An important group of circular migrants consists of seasonal migrants, those who combine activities in several places according to seasonal labour requirements. Six months is generally used as the maximum duration of a temporary move (Mberu, 2006; Pham \& Hill, 2008; Srivastava \& Sasikumar, 2003).

Therefore, seasonal migration for employment has become one of the most hard-wearing components of the livelihood strategies of people living in rural areas. Migration is not just by the very poor during times of crisis for survival and coping but has increasingly become an accumulative option for the poor and non-poor alike (Deshingkar \& Start, 2003). Therefore, this study draws few theoretical attentions, which are basically focused on the seasonal labour migration and livelihoods. Therefore, migration is one of the most important processes of population change and the livelihood diversification strategy. However, in the case of Nepal, particularly in the field of migration, numerous studies have done but its relationship with the livelihood opportunities, its diversification and dynamics are lacking behind. Regarding this gap, this study draws theoretically on the concept of the livelihoods and seasonal labor migration in the context of a rural farming economy. My assumption in this research paper is support to analyzes how seasonal migration as a livelihood activity contributes to the rural household in the middle hill of Nepal.

A livelihood is sustainable when it can cope with, recover from stresses and shocks, and maintain its capabilities and assets (Chambers \& Conway 1992; Tanner et al., 2015; Subedi 2017). However, Subedi argues that when livelihoods are not resilient; they become vulnerable (Subedi, 2017). This is the argument earlier addressed by (Turner, et al., 2003) with vulnerability is a condition in which people or systems are unable to cope with environmental and other disturbances and therefore become susceptible to change to a more undesirable state.

This study, therefore, examines the process of seasonal migration in light of the migration livelihood framework approach. The approach argues that migration is one of the most durable components of the livelihood strategies of people living in rural areas. It focuses on the need for a multi-disciplinary and people-centered perspective, and that the livelihoods of people are not restricted to one particular economic sector. According to the proponents of this approach, seasonal migration has become a common livelihood strategy of poor households which helps to smooth seasonal income fluctuations and earns extra cash so as to supplement income, which in turn, positively contribute to poverty reduction and development (Ellis, 2003). 


\section{Objective/Methodology}

The study aims at analyzing the relation between livelihoods and human mobility in two rural communities of Arghakhanchi district in Nepal and examining the differences in livelihood and human mobility patterns between households.

Seasonal labor migration, the focus of this study, is only one of several off-farm activities adopted by communities' in Arghakhanchi (Ghimire, 1997). Similarly, climate change is only one of many factors that drive migration in such communities (Black, Arnell, Adger, Thomas, $\&$ Geddes, 2013). Therefore, most of the inquiries were surrounded within climate change and the seasonal labour migration. The fieldwork was conducted in September 2014, in which a questionnaire for a household socioeconomic survey was used for the 321 households. In the household survey, the information about household demographics, landholdings and agricultural production, involvement in off-farm activities including migration, and income and expenditure patterns were collected.

Purposively, the number of households were selected and interviewed. In addition to that, a checklist is also used for focus group discussions. The key informant interview and focus group discussions were conducted immediately after household survey. In the fieldwork purpose, major dominant caste/ethnic groups were included from four rural municipalities: Jaluke, Jukena, Siddhara and Thada (Figure 1).

In focus group discussions, participants discuss a topic specified by the researcher. Four focus group discussions were held with 45 participants including 19 women. In the household survey, mainly discussed on the livelihood strategies, seasonal labor migration, climate change, copping strategies as well as off-farm activities on which the local people are engaged. Similarly, in the issue of migration, information gathered on migrants' work destinations, type of work, wages and savings, and their contribution to household economies, etc. Apart from migration, the focus group participants also described their involvement in a number of other off-farm income sectors. Both, the qualitative and quantitative information were gathered through the different types of methods, which were used in this research. The qualitative information acquired from the focus group discussions and key informant interview, which were supplemented by the quantitative information.

\section{Data collection and analysis}

The migrant source areas are Siddhara, Thada, Jukena and Jaluke rural municipalities of Arghakhanchi District in northwestern Nepal (27.9829 $9^{\circ}$, $83.0361^{\circ}$ E. Figure 1). Arghakhanchi district lies in the middle hill region of Nepal and it has just been connected to the national road network at Gorusinghe. Their poorly developed soils, harsh topography, limit the availability of arable land and the ability of local communities to support themselves through farming. However, agriculture is the backbone of the people in the study area. In this area, varieties of 

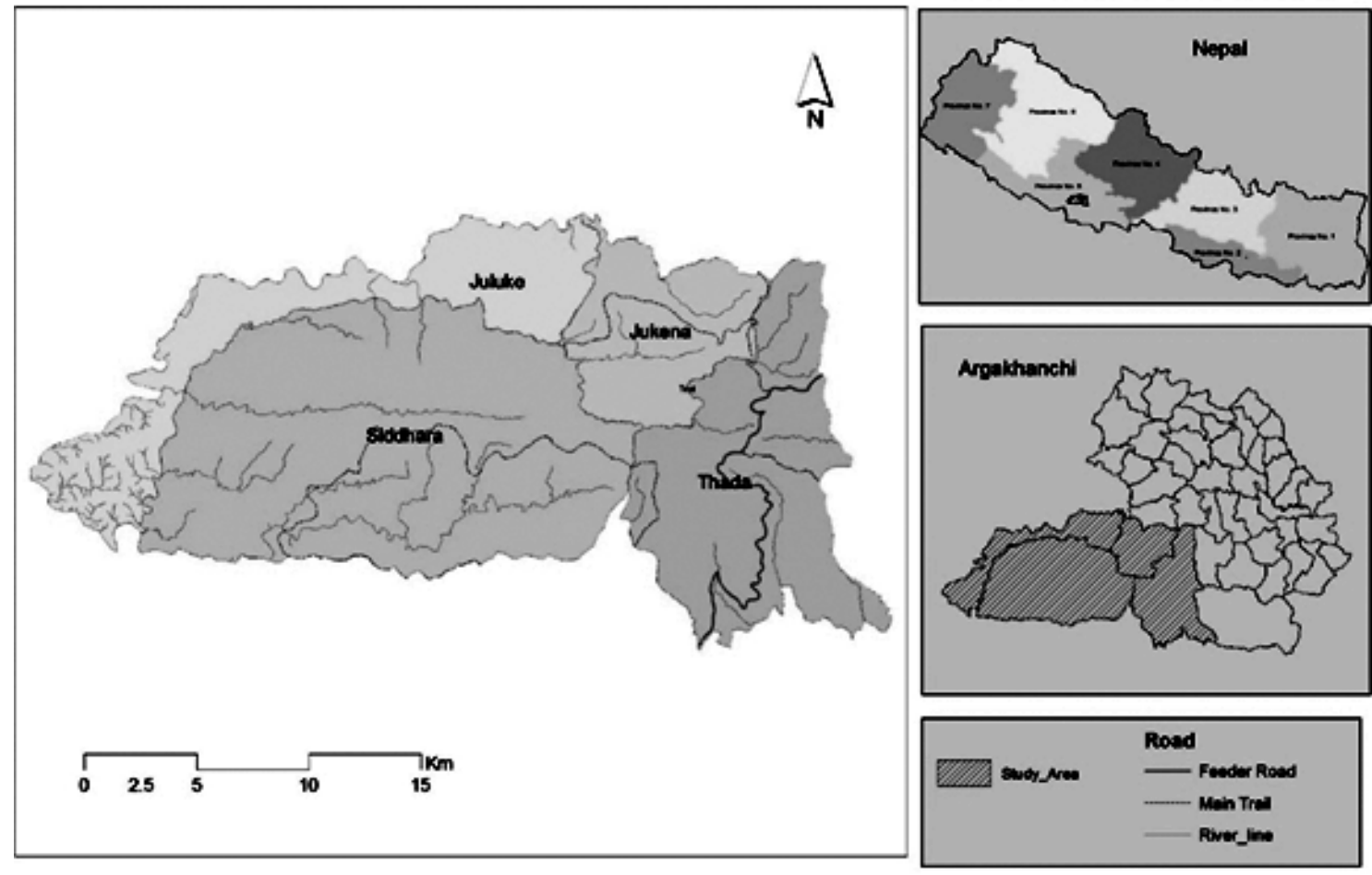

Figure 1: Map of the study area . (Map by Sher Bahadur Gurung)

cash and cereals crops are grown, such as paddy, maize, millets, wheat, pulses, other cereals and vegetables. They produce large amount in quantity and these products are extensively used for household consumption only. The selected rural municipalities also produce varieties of vegetables (cauliflower, cabbage, tomato, etc.) and fruits (orange, banana and lemon), which are also sources of agro-based income the rural people. Cattle, buffalo and sheep are also the noticeable sources of livestock farming in the study area.

In the study area of Arghakhanchi district, most of the family members are engaged in other sources of income than traditional agriculture like doing services, trade and foreign employment etc. Regarding the issue of foreign employment, the seasonal migration has brought significant changes in the rural livelihoods, particularly in the developing countries like Nepal and with special reference to my study area. Remittance is the dominant financial capital of the local people and have very strong social network (Gautam, 2017) and their major destinations for foreign employment are Korea, Gulf countries, India and Malaysia. 


\section{Results and discussion}

\section{Seasonal migration and livelihoods}

Out of 321 households surveyed in the study area, 186 (58 Percent) had at least one member who migrated in 2014. The average duration of an immigrant away from home is approximately 4.6 months. The variation on this average is relatively small and stands at 3.1 months.

\begin{tabular}{|l|r|r|}
\hline \multicolumn{4}{|l|}{ Table 1: Major destinations of seasonal migrants } \\
\hline Destination & No. of migrants' hhs & \multicolumn{1}{l|}{ Percentage } \\
\hline Uttarkhanda & 63 & 33.9 \\
\hline Bhopal & 48 & 25.8 \\
\hline Punjab & 33 & 17.7 \\
\hline Delhi & 16 & 8.6 \\
\hline Mumbai & 14 & 7.5 \\
\hline Other cities & 12 & 6.5 \\
\hline Total & 186 & 100.0 \\
\hline
\end{tabular}

Source: Field Survey, 2014.

For the majority, cities and towns in the Indian state of Uttarakhand, Bhopal and Punjab were the main destinations. From the selected villages of Arghakhanchi district, almost 34 percent were migrated as a seasonal migration at Uttarkhanda, whereas in Bhopal it is about 26 percent. Similarly, in Punjab it is about 18 percent are migrated in 2014. In addition to that, other cities, like Delhi, Mumbai as well as in southern part of the country (i.e. Chennai, Hyderabad, etc.) have almost 23 percent of the migrants. The adoption of seasonal migration showed a clear caste/ethnic dimension (Gautam, 2017), in which Dalits had the highest tendency to migrate (34 percent), which is followed by the Magar (31 percent) and Brahmin/Chhetri (27 percent); the other ethnic groups, such as Sanyasi, Gurung, etc had the smallest proportion of migrants.

\begin{tabular}{|c|c|c|}
\hline Caste/ethnicity & No. of migrants' hhs & Percentage \\
\hline Brahmin/Chhetri & 51 & 27.4 \\
\hline Magar & 58 & 31.2 \\
\hline Dalit & 63 & 33.9 \\
\hline Sanyasi & 2 & 1.1 \\
\hline Gurung & 9 & 4.8 \\
\hline Others & 3 & 1.6 \\
\hline
\end{tabular}




\begin{tabular}{|l|r|r|}
\hline Total & 186 & 100.0 \\
\hline
\end{tabular}

Source: Field Survey, 2014.

With the stalling of the rural economy people have begun to move from rural areas, particularly in the lean season of agriculture, to nearby or distant major city areas for employment in construction, the garment industry or in the informal sector as a street vendor, rickshaw puller, domestic helper, or waiter and labourer in small hotels (Breman, 1994; Deshingkar \& Farrington, 2009; Haberfeld et al., 1999; Vijay, 2005). Seasonal labor migration is an essential part of the lives and livelihoods of the poorest sections of the middle hill of Nepal and its significance is growing (Mosse et al., 2005). Similarly, the long-term migration appears to be dominated by males but in the case of seasonal migration, which is more frequent among the poorest of the poor and the tribal population, women and men migrate in almost equal numbers (Rao, 2005).

According to the local people of the study area, that seasonal migration as a source of livelihood that is practiced since the very beginning. During the agricultural lean season poor and ultrapoor prefer to migrate to Indian states and generate financial resources. As Gautam (2017) stated that, the farm labour demand is very high in during two periods in the mountainous region of the country; i.e. mid-May to mid-July, and mid-September to mid-November, Arghakhanchi district is no exception. During the winter season, there is a very less agricultural activity exists in the middle hill region. Therefore, the demand of farm labor is relatively less than in the rainy (Monsoon) season. However, in other non-farm activities, i.e. firewood collection, handicraft making, etc. mostly women carry out and male family members are nothing to do except household chores as well as the preparation of firewood in the forest. In addition to that, during the agricultural lean season, men family members prefer to migrate for economic reason. However, "modest migrants' earnings are, migration has a double benefit: It reduces home consumption without reducing the labour available for farming, and remittances, whatever the amount, help fill the food deficit and meet nonfood needs (Gautam, 2017)".

It seems that the seasonal migration to Indian cities have affected to the diverse livelihood assets in the study area. For instance, during the interview, majority of the participants noticed that they have positive change on their basic livelihood assets. Almost 84 percent of the respondents have significantly improved their economic assets due to seasonal migration to India. It follows by social capital (networks, social claims, social relations, etc.) with about 74 percent of the respondents, whereas physical capital (about 61 percent) is in the next, because they were able to reconstruct their house as well as other amenities related with physical assets. Overall, about 60 percent of the respondents realized that they have changed their livelihoods because of seasonal migration, but still about 33 percent people do not feel that they have any changed. Some of the worst-case scenario is also appeared in the study area. Almost eight percent of the respondents believe that they lost something due to seasonal migration. For example, they are in debt because of migration as well as miss their family member, deteriorate health condition and breakdown social relations. 


\begin{tabular}{|c|c|c|c|}
\hline Assets & Improve & Decline & $\begin{array}{c}\text { No } \\
\text { change }\end{array}$ \\
\hline Physical & 60.8 & 2.7 & 36.6 \\
\hline Human & 33.9 & 7.0 & 59.1 \\
\hline Economic & 83.9 & 10.2 & 5.9 \\
\hline Natural & 46.8 & 11.8 & 41.4 \\
\hline Social & 73.7 & 6.5 & 19.9 \\
\hline Total & 59.8 & 7.6 & 32.6 \\
\hline
\end{tabular}

Source: Field Survey, 2014.

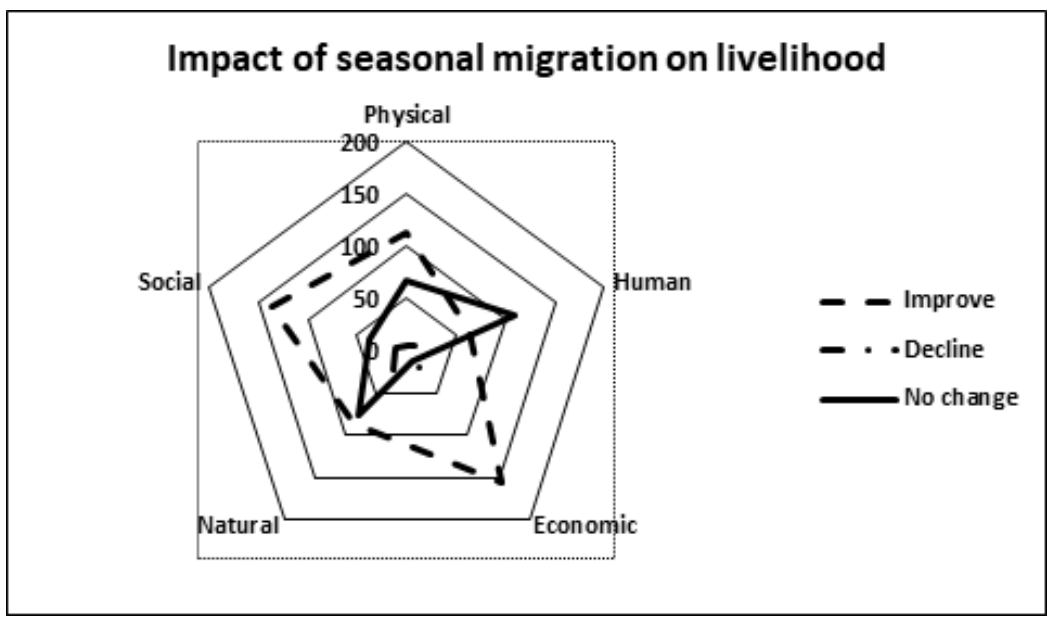

Figure 2 Status of livelihood assets.

Migrant vs non-migrant households: More than one-half of the sampled households provided migrant labor to some of the Indian cities. The average household from which migrant labor is provided is different on every dimension, from the average household not providing migrant labor. During the focus group discussion, participants claimed that about 60 percent of the seasonal migrant households' annual income is accumulated through wages for migrant labor, while the main source of income for non-migrant households are local salaries paid to its members as well as trade and services. In addition to that, the second most important source of income for all families is agriculture. However, while for migrant households, income from agriculture constitutes less than 20 percent of its total income, it is more than one-third of non-migrant households' total income. This is in part because non-migrant households have, on average, more assets than their migrant counterparts. Overall, however, migrant households' income is significantly higher than that of non-migrant households. Comparing the two types of households on the labor supply dimension yields mixed results. On the one hand, quantity of labor available to migrant households is larger 
than that available to non-migrant households, by approximately one-half of a person at prime working age. On the other hand, average education of non-migrant households' labor is higher than that of migrant households. The differing labor quality between the two types of households is further reflected in their employment opportunities. Members of non-migrant households hold better jobs than members of migrant households. Finally, the two types of households differ also in their social characteristics. Migrant households tend to belong more to the poor communities', to live in the less developed region of the district, and to stay out of the dominant communities of the elite groups.

\section{Who migrate, who left behind?}

As we have seen that, many potential migrant workers require others to look after their children, their animals, their house, or their land while they are away. In general, people who stay put while others in their household migrate often rely on the savings that the migrants bring back. Savings are both in cash and kind. The extent to which those who stay put have control over the use of the cash portion of savings varies. Those who migrate and those who stay put in a particular household are interdependent. However, the division of labor and of earnings between them is often contested and is likely to change over time. Regarding the survey households in the study area, mainly poor and male family members prefer to migrate and the better economic condition as well as female had a lower tendency to migrate. In addition to that, those people who do not intend to migrate households have better economic assets than those households who have at least one migrant from their households. About 91 percent of the seasonal migrants are men. Their average age is 29.5 years, and their education levels are higher than those found among other villagers are. On average, migrant laborers have more than 3 years of schooling. Only 32 percent of the sampled migrants were illiterate. About 30 percent of them were literate, yet did not complete the primary education level. The largest group among the seasonal migrants (38 percent) is that of people with post-primary school education. This profile indicates that the migrant workers are probably positively self-selected. Non-immigrants of the age of 15 years or above are both older and less educated than the immigrants. Their average age is 35 years and they completed, on average, 2.5 years of schooling. Even if we restrict the age of non-immigrants to include only those between the ages of 15-55 years, still their average years of schooling is lower than that of the immigrants.

\section{Remittances and livelihoods}

Many households depend partly on remittances in order to maintain a healthy state of economic wellbeing. As stated above that fifty-six percent of all sampled household income was derived from waged work and income from informal trade and casual work, etc. However, the survey result shows that most of the migrants worked in construction sites, agriculture sectors or as porters or other kind of helpers and cleaners in restaurants. An additional 36 percent of the households were obtained from remittances of money and goods from migrants, and the rest 
was from other sources, including agriculture. Out of 186 migrants in 2014 A.D. from selected VDCs of Arghakhanchi district, 87 percent of migrants remitted through formal channel (i.e. bank transfer, money transfer, etc.), whereas, the remaining seasonal migrants either use unofficial channel or prefer to carry the money home personally. Therefore, almost everyone was consistent in using the most preferred money transfer method. This is largely because it was perceived to be highly reliable. Similarly, the household survey indicates the peak frequency ( 71 percent) of remittance was once a month; 7 percent of migrants remitted at least twice a month, 16 percent did so once every three months or later, but the remaining is uncertain.

The participants expressed their experiences while they were also involved in the seasonal migration in India and told that all 3D type of jobs (dirty, dangerous and demanding) are poorly paid; after paying for their own food and lodging, migrants were only able to save, on average, about 20,000 Nepali Rupees (approximately US\$ 190) in 2014. After receive salary, they prefer to go for shopping to fulfill their household needs as well as other purposes, for instance, clothes, utensils, or small electronic items such as mobile phones. According to the local people that sometimes, the migrants come back to home without money because they spend all for household items. It seems that the seasonal migration sometimes create frustration to the local people.

\begin{tabular}{|l|c|c|}
\hline Table 4: Major sources of income & Non-migrant \\
\hline Categories & Migrant & 28 \\
\hline Salary & 9 & 29 \\
\hline Trade & 6 & 0 \\
\hline Remittance & 36 & 20 \\
\hline Wage labor & 29 & 18 \\
\hline NTFP collection & 13 & 5 \\
\hline Miscellaneous & 7 & 100 \\
\hline Total & 100 & \\
\hline
\end{tabular}

Source: Field Survey, 2014.

Even more than 50 percent of the sample households send their family members as seasonal migrants cover only 36 percent of their household income. It means that rest of the income they have to generate through different means of sources, i.e. wage labor, NTFP collection, salary and others for their livelihood. According to them, more than 60 percent of the migrant households are from the poor family and they do not have food sufficiency throughout the year only through the other sources of income rather than seasonal migration. Therefore, they compelled to migrate for food security as well as for their daily needs. However, the situations with the non-migrant households have differed than the migrant family. Almost eighty percent of the income they received from trade, salary and wage labor. 


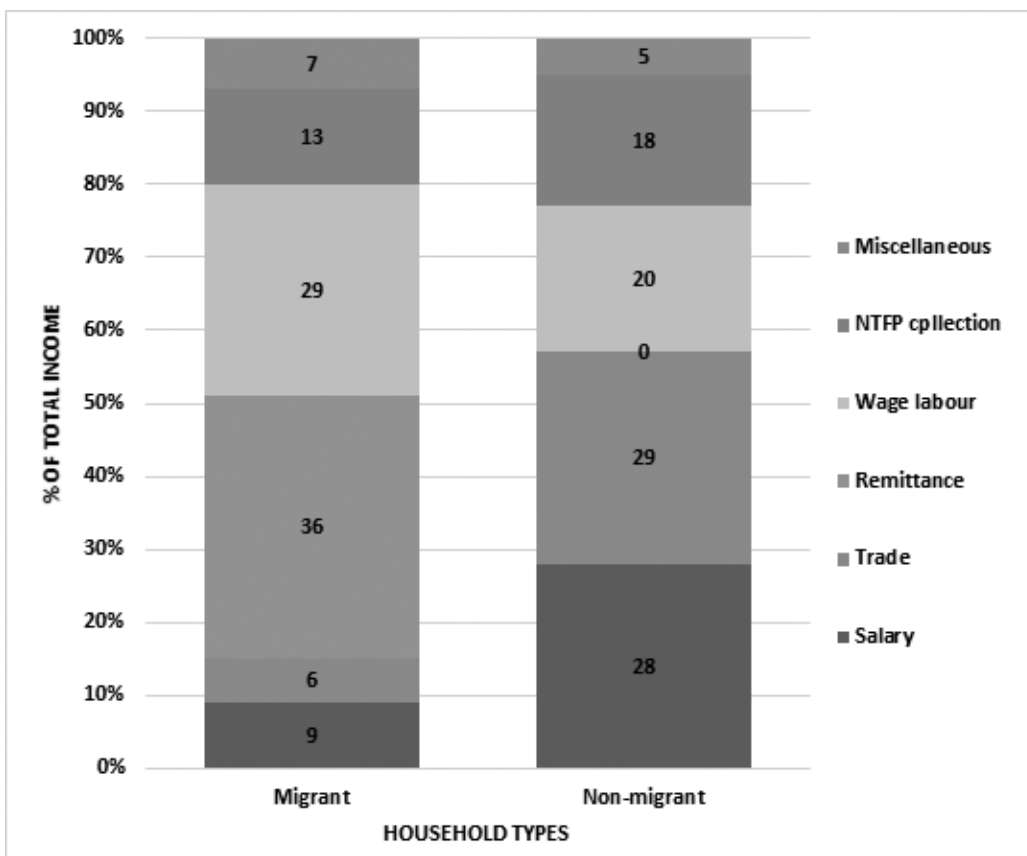

Figure 3: Off-farm income sources for Arghakhanchi households $(n=321)$. Note: After Gautam, 2017.

\section{Conclusion}

In Arghakhanchi, seasonal migration is a part of livelihood diversification strategy, which helps to minimize the food security related issue. Based on available evidence, seasonal migration can be viewed as making a positive contribution to the livelihoods of the rural poor. The evidence presented here indicates that, at least in the middle hill, such migration may be no more than a copping mechanism. In addition to that, however, seasonal migration seems capable of making a strong positive contribution to support for livelihoods deprivation in at least some households and help them to improve their living standards, but not accumulate other livelihood assets. Therefore, it ultimately helps to accumulate cash and support for the sustainability of the wellbeing. Seasonal migration also plays a vital role in maintaining production levels by 'lubricating' a labor market that is generally characterized by structural rigidities and inefficiencies (Acharya, 2000; Seddon \& Subedi, 2000). Undoubtedly, this contribution could be greatly improved to the benefit of consumers, producers and migrants if labor markets were to be made more efficient through improved information flows and reduced transaction costs. However, the low paying jobs in Indian cities they are not able to accumulate savings and supportive role to play to reduce the household food deficit.

Therefore, seasonal migration in the middle hill district, like Arghakhanchi results from highly complex push factors, such as high levels of poverty and food insecurity, as well as pull factors, such as seasonal employment opportunities elsewhere, with flows mainly going from the 
economically poor regions to the well-off cities within the county and better developed areas in Indian cities. Migration is on the rise, with new areas employment arising faster than older ones are disappearing. In addition to that, seasonal labor migration is an increasing phenomenon, and in the poorest villages of the study area, it is the main livelihood source for the poor households. The evidences clearly reflect that in the study area, agricultural work dominates, but there are important flows for non-agricultural work.

While the present survey adds to existing knowledge on seasonal labor migration at the macro level, much more needs to be done before concrete new policy measures can be recommended. A fully resourced study needs to be conducted if the dimensions and dynamics of this important issue are to be properly understood.

\section{References}

Acharya, M. (2000) Labour market development and poverty (with Focus on Opportunities for Women) in Nepal, Kathmandu: Thanka Prasad Acharya Foundation in Co-operation with Friedrigh-Ebert-Shiftung.

Acosta P, Calderon C, Fajnzylber P, and Lopez H. (2008). What is the impact of international remittances on poverty and inequality in Latin America? World Development 36:89-114.

Bilsborrow, R. E., Oberai A. S., and Standing G. (1984), Migration Surveys in Low Income Countries: Guidelines for Survey and Questionnaire Design, London and Sydney, Croom Helm.

Black, R Arnell NW, Adger WN, Thomas, D, and Geddes A. (2013). Migration, immobility and displacement outcomes following extreme events. Environmental Science and Policy 27: S32-S43.

Brauw, A. D. (2007). Seasonal migration and agriculture in Viet Nam, ESA Working Paper No. 07-04, Agricultural Development Economics Division, The Food and Agriculture Organization of the United Nations.

Breman, J. (1978). Seasonal migration and co-operative capitalism: crushing of cane and of labour by sugar factories of Bardoli. Economic and Political Weekly, 13(31/33), 1317-1360.

Breman, J. (1994). Wage hunters and gatherers: Search for work in the urban and rural economy of South Gujarat, Delhi, Oxford University Press.

Breman, J. (1996), Footloose labour: Working in India's informal economy, Cambridge, Cambridge University Press.

Chambers R, and Conway G. (1992). Sustainable rural livelihoods: Practical concepts for the 21st century. IDS Discussion Paper 296. Brighton, United Kingdom: Institute of Development 
Studies(UK).

de Haan, A. 1999. Livelihoods and poverty: The role of migration- A critical review of the migration literature. Journal of Development Studies. Vol. 36, No.2.

de Haan, A. 2000. Migrants, livelihoods, and rights: The relevance of migration in development policies. Social Development Working Paper No.4.London: DFID.

Deshingkar P., and Farrington J. (2006). Rural labour markets and migration in South Asia: Evidences from India and Bangladesh, background paper for the world development report, 2008, London, Overseas Development Institute.

Deshingkar P., and Farrington J. (2009). Circular migration and multilocational livelihood strategies in rural India, New York, Oxford University Press.

Deshingkar P., and Start D. (2003), Seasonal migration for livelihoods in India: Coping, accumulation and exclusion. Overseas Development Institute, Working Paper 220, London, Overseas Development Institute.

Deshingkar, P. 2004. Understanding the implication of migration for pro-poor agricultural growth. Paper prepared for the DAC POVNET Agricultural Task Group Meeting. Helsinki: Overseas Development Institute.

Ellis F. (2000). The determinants of rural livelihood diversification in developing countries. Journal of Agricultural Economics 51:289-302.

Ellis, F. (2003). A livelihoods approach to migration and poverty reduction. Paper Commissioned by the Department for International Development (DFID), University of East Anglia, Norwich NR4 7TJ.

Gautam. Y. (2017). Seasonal migration and livelihood resilience in the fae of climate change in Nepal. Mountain Research Development, 37 (4): 436-445.

Ghimire, B N. (1997). Migration and employment: A case study of Sandikharka VDC of Arghakhachhi District, MA Thesis (Geography), TU, Nepal.

Haberfeld Y, Menaria RK, Sahoo BB, and Vyas RN. (1999). Seasonal migration of rural labor in India. Population Research and Policy Review 18:471-487.

Hollema S, Pahari K, Regmi P, and Adhikari J. (2008). Passage to India: Migration as a coping strategy in times of crisis in Nepal. Kathmandu, Nepal: World Food Programme, Nepal Development Research Institute.

Hugo, G.J. (1982). Circular migration in Indonesia, Population and Development Review, 8(1), 59-83. 
Kosinski L. A., and Prothero R. M. (1975), People on the move, London, Methuen and Co.

Kothari, U. 2002. Migration and chronic poverty. Institute for Development Policy and Management Working Paper No 16, University of Manchester.

Lam T. Q., John B. R., Chamratrithirong A., and Sawangdee Y. (2007). Labour migration in Kanchanaburi demographic surveillance system: characteristics and determinants. Journal of Population and Social Studies, 16(1), 117-144.

Massey D. (1990). Social structure, household strategies, and cumulative causation of migration. Population Index, 56(1), 3-26.

Mberu B. U. (2006). Internal migration and household living conditions in Ethiopia. Demographic Research, 14(21), 509-540.

McDowell, C. and de Haan, A. (1997). Migration and sustainable livelihoods: A critical review of the literature. IDS Working Paper 65. Brighton: IDS.

Mosse D., Gupta S., and Shah V. (2005). On the margins in the city: adivasi seasonal labour migration in western India.Economic and Political Weekly, July, 3025-3038.

Olimavo, S. and Olimov, M. (2007). Labour migration from mountain areas in the central Asian region: Good or evil? Mountain Research and Development, 27 (2): 104-108.

Pham B. N., and Hill P. S. (2008). The role of temporary migration in rural household economic strategy in a transitional period for the economy of Vietnam. Asian Population Studies, $4(1), 57-75$.

Rao, N. (2005). Power, culture and resources in gendered seasonal migration from Santhal Parganas. in Aray S., Roy A. (eds.), Poverty, Gender and Migration. New Delhi: Sage Publications.

Rao, N., and Rana K. (1997). Women's labour and migration: the case of the Santhals. Economic and Political Weekly, 32(50), 3187-3189.

Rogaly, B. (1998). Workers on the move: seasonal migration and changing social relations in rural India.Gender and Development, 6(1), 21-29.

Rogaly, B., Biswas J., Coppard D., Rafique A., Rana K., and Sengupta A. (2001). Seasonal migration, social change and migrants' rights: lessons from West Bengal.Economic and Political Weekly, 36(49), 4547-4559.

Seddon, D. and Subedi, B. P. (2000) Labour Markets and the Poor, Report for DFID Nepal, Norwich: Overseas Development Group, University of East Anglia (September). 
Skeldon, R. (2002). Migration and Poverty. Asia-Pacific Population Journal 17.

Srivastava, R., and Sasikumar S.K. (2003). An overview of migration in India, its impacts and key issues. Paper presented at Regional Conference on Migration, Development and Pro-Poor Policy Choices in Asia, at Dhaka. Available: http://www.eldis.org/assets/Docs/upload/ 1/ document/0903/Dhaka. CP_2.pdf. Accessed, 2018 March 3.

Subedi, BP. (2017). Livelihood diversification amidst shocks and stresses in the mountains in Nepal: Experiences from villages of Mustang. In A. Li et al. (eds.), Land cover change and its eco-environmental responses in Nepal. Springer Geography, DOI 10.1007/978981-10-2890-8_15: 327-358

Tanner, T, Lewis D, Wrathall D, Bronen R, Cradock-Henry N, Huq S, Lawless C, Nawrotzki R, Prasad V, and Rahman MA. (2015). Livelihood resilience in the face of climate change. Nature Climate Change 5:23-26.

Vijay, G. (2005). Migration, vulnerability and insecurity in new industrial labour markets. Economic and Political Weekly, June, 2304-2312.

World Bank (2017). Personal remittances, received (\% of GDP). World Bank Online Data Portal. $\quad \underline{\text { https://data.worldbank.org/indicator/BX.TRF.PWKR.DT.GD. }}$ ZS?locations $=$ NP\&page $=3$; accessed on 09 October 2017.

Yang X. (1992). Temporary migration and its frequency from urban households in China. Asia Pacific Population Journal, 7(1), 27-50.

Zelinsky W. (1971). The hypothesis of the mobility transition. Geographical Review.41(2), 219249. 